\title{
THE DIVERSITY OF CADDISFLIES (INSECTA, TRICHOPTERA) SPECIES IN TIMIS, RIVER CATCHMENT AREA (WESTERN ROMANIA)
}

\author{
Mălina PÂRVU * and Lucian PÂRVULESCU **
}

\begin{abstract}
* West University of Timişoara, Faculty of Chemistry, Biology, Geography, Department of Biology Chemistry, 16A Pestalozzi Street, 300115, Timişoara, Romania, malina.pirvu@cbg.uvt.ro

** West University of Timişoara, Faculty of Chemistry, Biology, Geography, Department of Biology Chemistry, 16A Pestalozzi Street, 300115, Timişoara Romania, lucian.parvulescu@cbg.uvt.ro
\end{abstract}

DOI: $10.2478 /$ trser-2013-0039.

KEYWORDS: Trichoptera, water quality, bioindicators, western Romania.

\section{ABSTRACT}

In order to determine the benthic macro invertebrates communities role as bioindicators, researchers worldwide carried out analyses into the structure, dynamics and diversity of the different groups as well as into the physical-chemical factors. A total of twenty one species of caddisfly larvae were identified in the study. Numerical abundance, frequency and diversity values recorded for the caddisfly species varied according to the physicalchemical conditions specific to each sample collecting station. The physical and chemical parameters monitored in Timis River water catchment basin have corresponded with the limits of the Ministry of Environment and Water Management (MEWA) Order 161/2006, which states the ecological status of surface bodies of water with, few exceptions being identified.

Timiș.

RÉSUME்: La diversité des trichoptères dans le bassin hydrographique de la rivière de

Dans le but d'établir le rôle de bioindicateur des communautés de macro-invertébrés benthiques, les chercheurs du monde entier ont effectué des études d'analyse de la structure, de la dynamique et de la diversité des différents groupes, en relation avec l'étude des agents physico-chimiques. Dans la présente étude, 21 espéces de trichoptères au stade larvaire ont été identifiés. Les valeurs d'abondance en pourcentage, de la fréquence et de la diversité biologique relative aux larves de trichoptéres identifiées, ont varié par rapport aux modifications des paramétres physico-chimiques spécifiques à chaque station de collecte d'échantillons. Les valeurs des paramètres physico-chimiques relevées dans le bassin hydrographique de Timiş sont conforment aux normes établies par le Ministère des Eaux et de la Protection de l'Environnement 161/2006, qui prévoit un bon état écologique des cours d'eau; quelques exceptions sont tout de même à noter. râului Timiş.

REZUMAT: Diversitatea speciilor de trichoptere în zona bazinului hidrografic al

În vederea determinării rolului de bioindicatori al comunităților de macronevertebrate bentonice, cercetători din întreaga lume au desfăşurat studii de analiză a structurii, dinamicii și diversității diferitelor grupe, alături de cele privind factorii fizico-chimici. În prezentul studiu, au fost identificate 21 specii de trichoptere în stadiul larvar. Valorile abundenței numerice procentuale, ale frecvenței și diversităţii biologice privind larvele de trichoptere identificate au variat în raport cu modificările parametrilor fizico-chimici specifici fiecărei stații de colectare a probelor. Valorile parametrilor fizico-chimici monitorizați în bazinul hidrografic al Timișului au corespuns limitelor Ordinului Ministrului Apelor și Protecției Mediului 161/2006, care prevede starea ecologică a corpurilor de apă, fiind identificate câteva excepții. 


\section{INTRODUCTION}

The ecological monitoring of the quality of the water supposes the use of multiple methods of chemical, physical and biological analysis, its importance being given by the specific adaptations to the specific habitat conditions (Ouyang, 2005; Guilpart et al., 2012). The higher the interest, the more the anthropic influences become stronger with direct influence upon the natural ecosystems of aquatic types (Böhmer et al., 2004; Van Hoey et al., 2010). The monitoring programs for water quality has become a major concern in most of European countries, and each country using their own or borrowed system. The joint element being represented by the macro fauna that are frequently used as an indicator (Böhmer et al., 2004; Borja et al., 2007).

The studies carried out presently place caddisflies as an instrumental group of biological indicators, due to their sensitive to alteration of water quality (Azrina et al., 2006; Li et al., 2010; Wesolek et al., 2010). The spread of the different species of caddisflies through the aquatic systems is given by a series of key factors, one of which is the critical role played by the anthropic impact (Englund et al., 1997; Fernández-Aláez et al., 2002; Roy et al., 2003; Kail et al., 2012; Almeida et al., 2013) and ecologic and habitat preferences of each and every species (Hildrew and Edington, 1979; Boyero and Barnard, 2004; Hughes, 1978).

Timiș drainage area (TDA) $\left(5.673 \mathrm{~km}^{2}\right)$ represents, together with Bega drainage area, (BDA) $\left(2.362 \mathrm{~km}^{2}\right)$ approximately $43 \%$ of the surface of Banat hydrographic space located in the western part of the country (Ilie, 2007).

The main purpose of this study is to analyse the diversity and the structure of the Trichoptera community in the target area for the purpose of establishing a natural and/or anthropic impact, either present or potential.

\section{MATERIAL AND METHODS}

\section{Benthos samples collection}

In the summer of 2009 a field investigation was conducted in Timiş River water catchment area, western Romania. A total of 19 semi-quantitative samples ( 1 sample/station) were processed using a hand net (meshes of $250 \mu \mathrm{m}$ ), each of the sites investigated were approximately $200 \mathrm{~m}$ in length. In the laboratory, the identification of the organisms was conducted on a species level (Waringer and Graf, 1997; Wallace et al., 2003). Organisms were not identified in the first stages of existence at a species level, they did not feature fully developed morphological traits to allow a proper analysis. 349 individuals were processed.

Localizing the sampling stations and processing the data

The localization of sampling stations according to the code number is as follows:

S1, Moravița $\left(45^{\circ} 21^{\prime} 25^{\prime}\right.$ N N, 21 ${ }^{\circ} 45^{\prime} 51^{\prime \prime}$ E, altitude - alt. $\left.240 \mathrm{~m}\right)$; S2, Străjești $\left(45^{\circ} 23^{\prime} 08^{\prime \prime}\right.$ N, $22^{\circ} 02^{\prime} 43^{\prime \prime}$ E, alt. $\left.280 \mathrm{~m}\right)$; S3, Valea Runc $\left(45^{\circ} 22^{\prime} 46^{\prime \prime}\right.$ N, $22^{\circ} 07^{\prime} 47^{\prime \prime}$ E, alt. 320

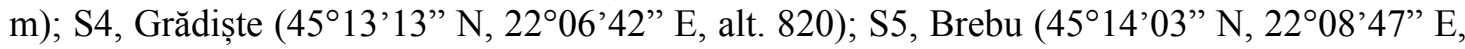
alt. $860 \mathrm{~m}$ ); S6, Cernei $\left(45^{\circ} 12^{\prime} 39^{\prime \prime} \mathrm{N}, 2^{\circ} 15^{\prime} 53^{\prime \prime} \mathrm{E}, 270 \mathrm{~m}\right)$; S7, Armeniş (4514’21” N,

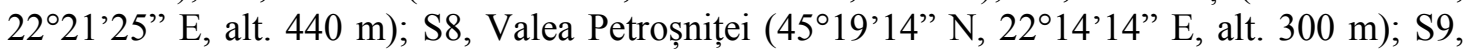

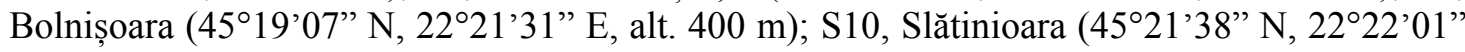
E, alt. $395 \mathrm{~m}) ; \mathrm{S} 11$, Valea Vidra $\left(45^{\circ} 25^{\prime} 05^{\prime \prime} \mathrm{N}, 22^{\circ} 31^{\prime} 25^{\prime \prime} \mathrm{E}\right.$, alt. $\left.620 \mathrm{~m}\right)$; S12, Mânzul

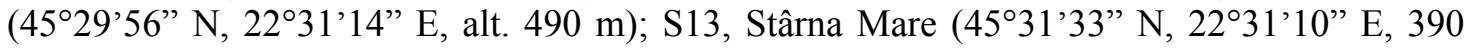

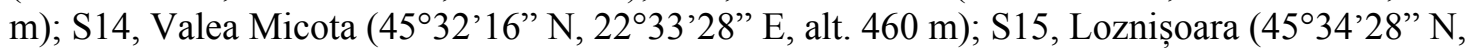
$22^{\circ} 29^{\prime} 35^{\prime \prime}$ E, $415 \mathrm{~m}$ alt.); S16, Glimboca $\left(45^{\circ} 31^{\prime} 19^{\prime \prime} \mathrm{N}, 2^{\circ} 19^{\prime} 16^{\prime \prime} \mathrm{E}\right.$, alt. $\left.295 \mathrm{~m}\right) ; \mathrm{S} 17$,

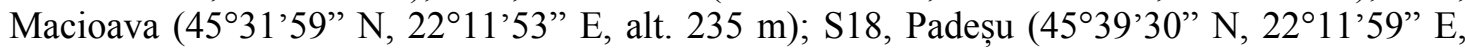

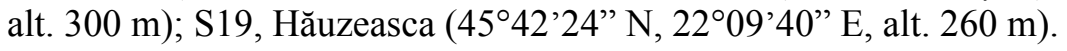


In each of the sampling sectors, the water temperature $\left({ }^{\circ} \mathrm{C}\right)$, average river width, depth $(\mathrm{m})$ and percentage of riparian tree coverage (\%) were estimated. Along with several physicochemical parameters: $\mathrm{pH}$, dissolved oxygen $\left(\mathrm{mg} \mathrm{l}^{-1}\right)$, conductivity $\left(\mu \mathrm{S} \mathrm{cm}^{-1}\right)$, water hardness $\left({ }^{\circ} \mathrm{dH}\right)$, dissolved calcium and magnesium ions $\left(\mathrm{mg} \mathrm{l}^{-1}\right)$, dissolved inorganic nitrogen forms $(\mathrm{N}-$ nitrate, $\mathrm{N}$-nitrite and $\mathrm{N}$-ammonia) $\left(\mathrm{mg} \mathrm{l}^{-1}\right)$ and soluble reactive phosphorus (SRP) (mg $\left.\mathrm{l}^{-1}\right)$. These indicators were recorded with HACH-Lange (Düsseldorf, Germany) multi-parameter and spectrophotometer field equipment following the standard procedure for each parameter. Each parameter was analysed using one subsample in each sampling sector.

The abundance $\mathrm{A}=\left(\mathrm{n}_{\mathrm{i}} \mathrm{N}^{-1}\right) * 100$ and frequency $\mathrm{F}=\left(\mathrm{N}_{\mathrm{i}}^{*} 100\right) \mathrm{N}_{\mathrm{p}}^{-1}$ were further calculated, where $n_{i}$ represents the total number of individuals for the i species, $S_{p}$ the total researched area, $\mathrm{N}$ the total number of individuals belonging to all species (from the sample or samples studied), $\mathrm{N}_{\mathrm{i}}$ the number of stations where i species were identifies, $\mathrm{N}_{\mathrm{p}}$ total number of stations (Stan, 1995). The Shannon-Wiener (SW-DI) diversity index, H' $=-\Sigma p_{i} \log _{2} p_{i}$ and the Pielou equitability index (PEI) $\mathrm{E}=\mathrm{H}^{\prime} / \mathrm{H}_{\max }$, where $\mathrm{p}_{\mathrm{i}}$ represents species abundance calculated according to $\mathrm{p}_{\mathrm{i}}=\mathrm{n}_{\mathrm{i}} \mathrm{N}^{-1}, \mathrm{H}_{\max }=\log \mathrm{S}, \mathrm{S}$ the total number of species (Sîrbu and Benedek, 2004) were also determined.

\section{RESULTS}

The mean values of the maximum river bed stretch and water depth for the 19 stations were $2.71 \pm 0.49 \mathrm{~m}$ and $0.43 \pm 0.10 \mathrm{~m}$. The mean values of the minimum river bed stretch and water depth for the 19 stations were $1.04 \pm 0.32 \mathrm{~m}$ and $0.08 \pm 0.02 \mathrm{~m}$. The mean values of the coverage degree of the river bed was $57.95 \pm 13.62 \%$ and the sub-layer analyzed was mostly made up of stones, boulders and gravel.

After processing the samples, 21 species included in 12 genera and 7 families were identified as follows: Fam. Glossosomatidae: genus Glossosoma (G. conformis Neboiss, 1963), Fam. Hydropsychidae: genus Hydropsyche (H. angustipennis Curtis, 1834; H. fulvipes Curtis, 1834; H. incognita Pitsch, 1993; H. instabilis Curtis, 1834; H. pellucidula Curtis, 1834), Fam. Limnephilidae: genus Chaetopterygopsis (C. maclachlani Stein, 1874), genus Halesus (H. digitatus von Paula Schrank, 1781; H. rubricollis Pictet, 1834), genus Micropterna (M. lateralis Stephens, 1837), genus Potamophylax (P. latipennis Curtis, 1834; P. nigricornis Pictet, 1834; P. luctuosus Piller and Mitterpacher, 1783), Fam. Philopotamidae: genus Philopotamus (P. montanus Donovan, 1813), Fam. Psychomyiidae: genus Lype (L. phaeopa Stephens, 1836), genus Psychomyia (P. pusilla Fabricius, 1781), Fam. Rhyacophilidae: genus Rhyacophila ( $R$. dorsalis Curtis, 1834; R. obliterata McLachlan, 1863; $R$. tristis Pictet, 1834), Fam. Sericostomatidae: genus Sericostoma (S. personatum Kirby and Spence, 1826), genus Oecismus (O. monedula Hagen, 1859).

The Hydropsyche genus featured the highest number of species (5), followed by the rest, with three species for Potamophylax sp. and Rhyacophila sp. respectively, and with one species for each of the rest. Their distribution according to the sample collection stations is shown in table 1.

The analysis of the percentage numerical abundance showed a high value for the $H$. incognita species $(94.74 \%)$, followed by the other two species, but at a great distance from the point of view of value identified, with $31.58 \%$ each (Fig. 1). The lowest values were established for 7 of the 21 species of caddisflies identified in total, with values of $5.26 \%$ each. In terms of frequency, the highest values were established for two species of the genus Hydropsyche, $H$. pellucidula and $H$. incognita with $23.21 \%$ and respectively $22.64 \%$ (Fig. 2). The lowest frequency was set for $H$. digitatus $(0.29 \%)$. 
After calculating the SW-DI index, a maximum value of diversity for S14 (0.76) and S1 (0.70) were established, the lowest value of 0.15 being set for 5 sampling stations (S2, S5, S13, S15, S17) (Fig. 3). These low values were also established by calculating the PEI index for the same sampling stations, the maximum being identified for S8 and S16 with 1.04 and respectively 1.03 (Fig. 4).

Table 1: Caddisflies species distribution in Timiș River water catchment area, 2009.

\begin{tabular}{|c|c|c|c|c|c|c|c|c|c|c|c|c|c|c|c|c|c|c|c|c|c|}
\hline & 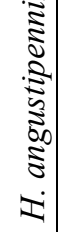 & 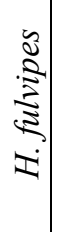 & 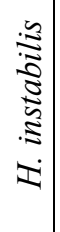 & 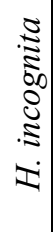 & 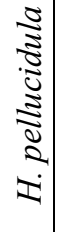 & 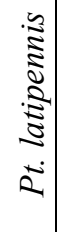 & 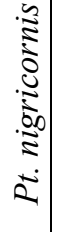 & 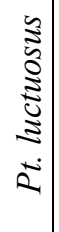 & 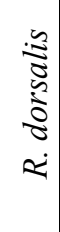 & 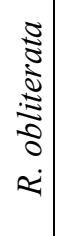 & 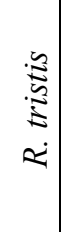 & 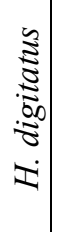 & 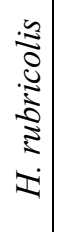 & 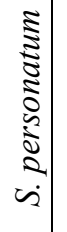 & 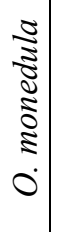 & 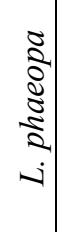 & 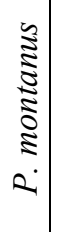 & $\begin{array}{l}: \vec{z} \\
\bar{z} \\
\vdots \\
\vdots \\
\vdots \\
z \\
z\end{array}$ & \begin{tabular}{c}
$:$ \\
\multirow{3}{*}{} \\
$\vdots$ \\
0 \\
0
\end{tabular} & 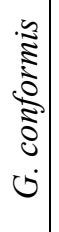 & 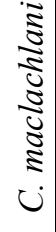 \\
\hline S1 & & $\mathrm{x}$ & $\mathrm{X}$ & $\mathrm{X}$ & & & & & & $\mathrm{X}$ & $\mathrm{x}$ & $\mathrm{x}$ & & & & & & & & & \\
\hline S2 & & & & $\mathrm{X}$ & & & . & & & & 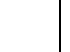 & & & & & & & & & & \\
\hline S3 & & & & $\mathrm{x}$ & $x$ & & $\mathrm{x}$ & & & & $\mathrm{x}$ & & & & & & & & & & \\
\hline S4 & $\mathrm{X}$ & & & $\mathrm{x}$ & & & & & & & & & & & & & & & & & \\
\hline S5 & & & & $\mathrm{X}$ & & & & & & & & & & & & & & & $\mathrm{x}$ & & \\
\hline S6 & & & & $\mathrm{X}$ & & & & & & & . & & & & & & & & & & \\
\hline S7 & & & & $\mathrm{x}$ & $\mathrm{X}$ & $\mathrm{x}$ & $\mathrm{x}$ & & $x$ & & $x$ & & & $\mathrm{x}$ & $x$ & & $\mathrm{x}$ & $\mathrm{x}$ & & & \\
\hline S8 & & & & $\mathrm{x}$ & & $x$ & & $\mathrm{X}$ & $\mathrm{x}$ & & & & & & $x$ & & $x$ & $x$ & & & \\
\hline S9 & $\mathrm{x}$ & & & $\mathrm{X}$ & & & & & & $\mathrm{X}$ & & & & $\mathrm{x}$ & & & & & & & \\
\hline S10 & & & $x$ & $\mathrm{x}$ & $\mathrm{X}$ & & & & & $x$ & $x$ & & $x$ & & & & & & & & $\mathrm{x}$ \\
\hline S11 & & & & $\mathrm{X}$ & & $\mathrm{X}$ & & $\mathrm{x}$ & $\mathrm{X}$ & & & & & & & & & & & & \\
\hline $\mathrm{S} 12$ & & & & $\mathrm{x}$ & $\mathrm{X}$ & & & & & & & & & & & & & & & & \\
\hline $\mathrm{S} 13$ & & & & $\mathrm{X}$ & & $\mathrm{X}$ & & & $\mathrm{X}$ & & & & & & & & & & & & \\
\hline S14 & & & $x$ & $\mathrm{x}$ & & $\mathrm{x}$ & & & $\mathrm{x}$ & & & & & $\mathrm{X}$ & $\mathrm{x}$ & $\mathrm{x}$ & & & & $\mathrm{x}$ & \\
\hline S15 & & & & $\mathrm{x}$ & & & & & & & & & & & & & & & & & \\
\hline S16 & & & & $\mathrm{X}$ & & & & & & & & & & & & & & & & & \\
\hline S17 & & & & $\mathrm{x}$ & $\mathrm{X}$ & & & & & & & & & & & & & & & & \\
\hline S18 & & & & $\mathrm{x}$ & $\mathrm{X}$ & & & & & & & & & & & & & & & & \\
\hline S19 & & & & $\mathrm{X}$ & & $\mathrm{x}$ & & & $\mathrm{X}$ & & & & & $\mathrm{x}$ & & & & & & & \\
\hline
\end{tabular}




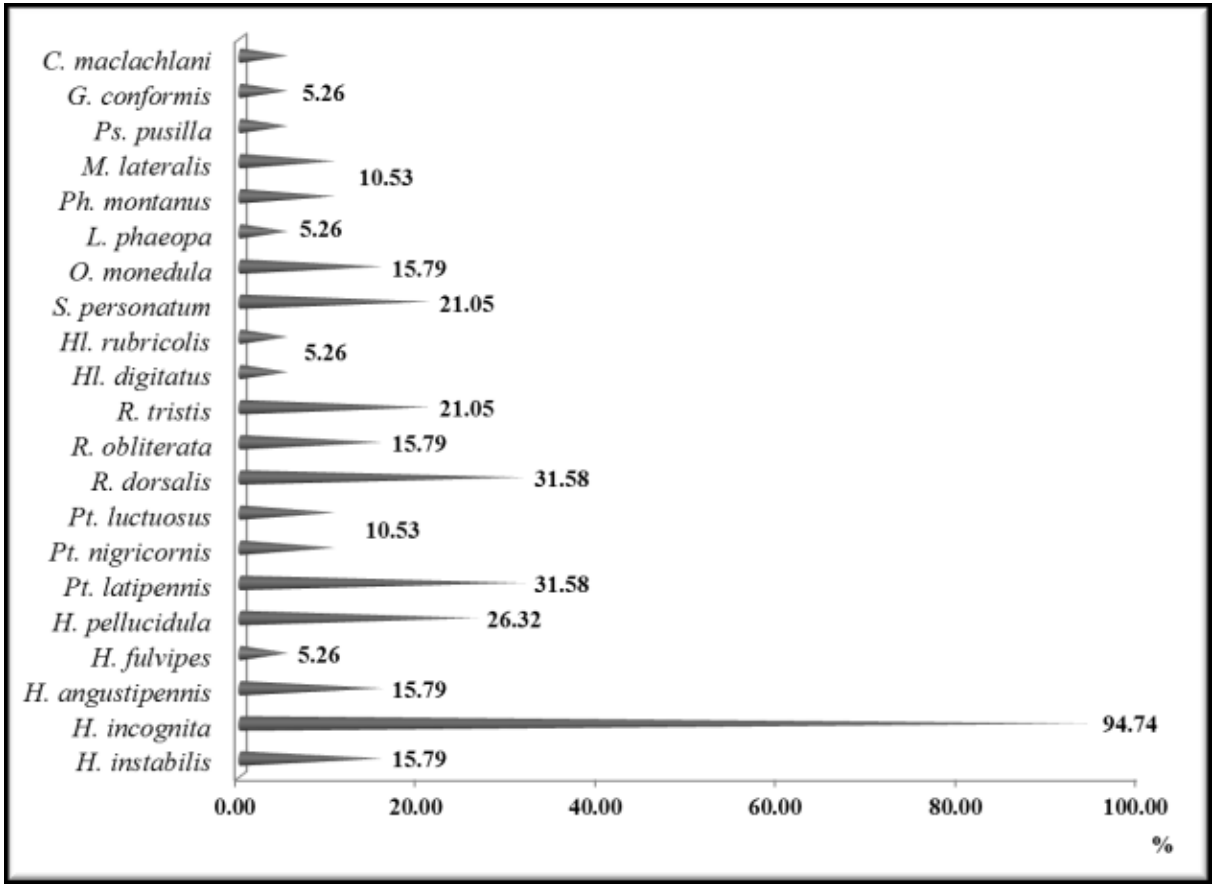

Figure 1: Percentage numerical abundance (\%) of caddisflies species in Timiș River water catchment area, 2009.

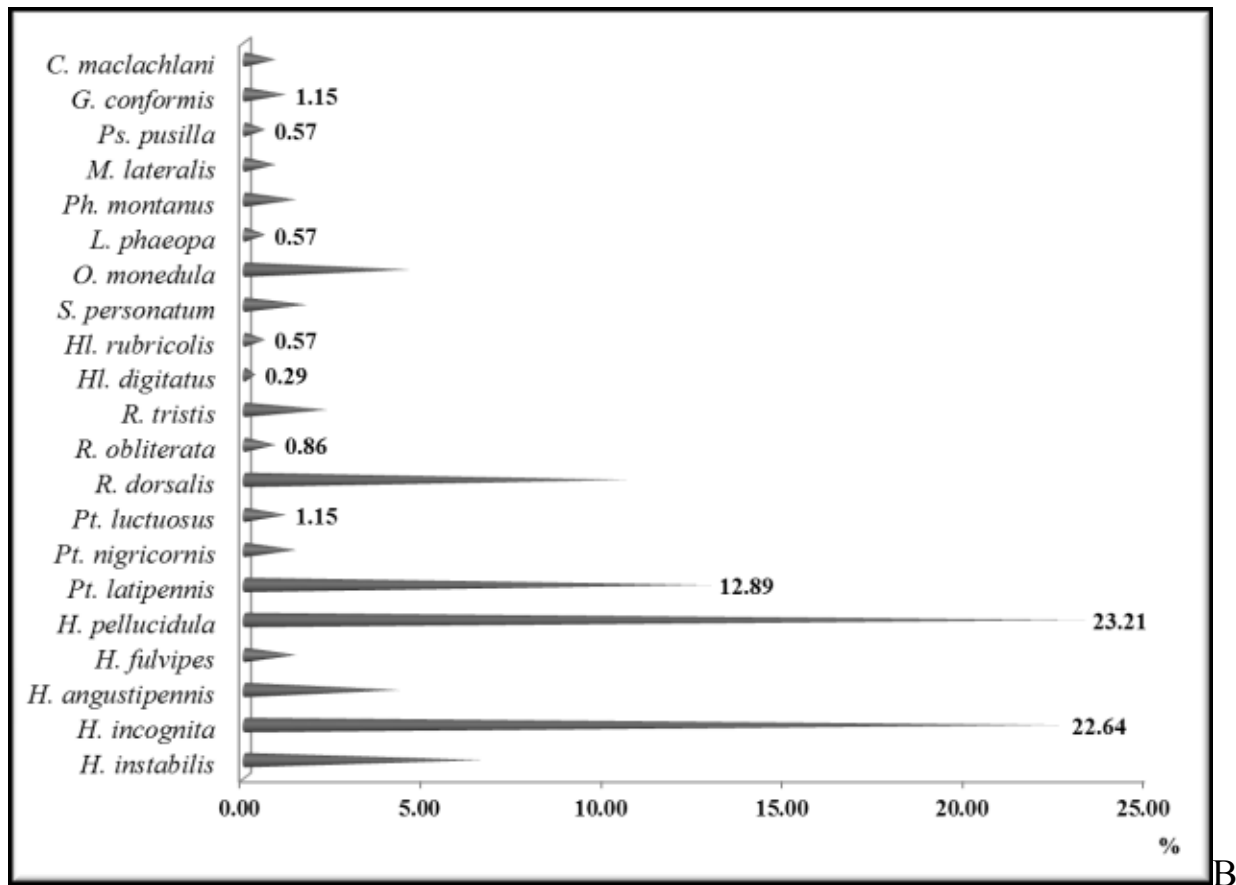

Figure 2: Frequency (\%) of caddisflies species in Timiș River water catchment area, 2009. 
The SW index and PEI values corresponding to the 19 sampling stations for the summer of 2009 in Timiș River water catchment basin were presented in figure 3.

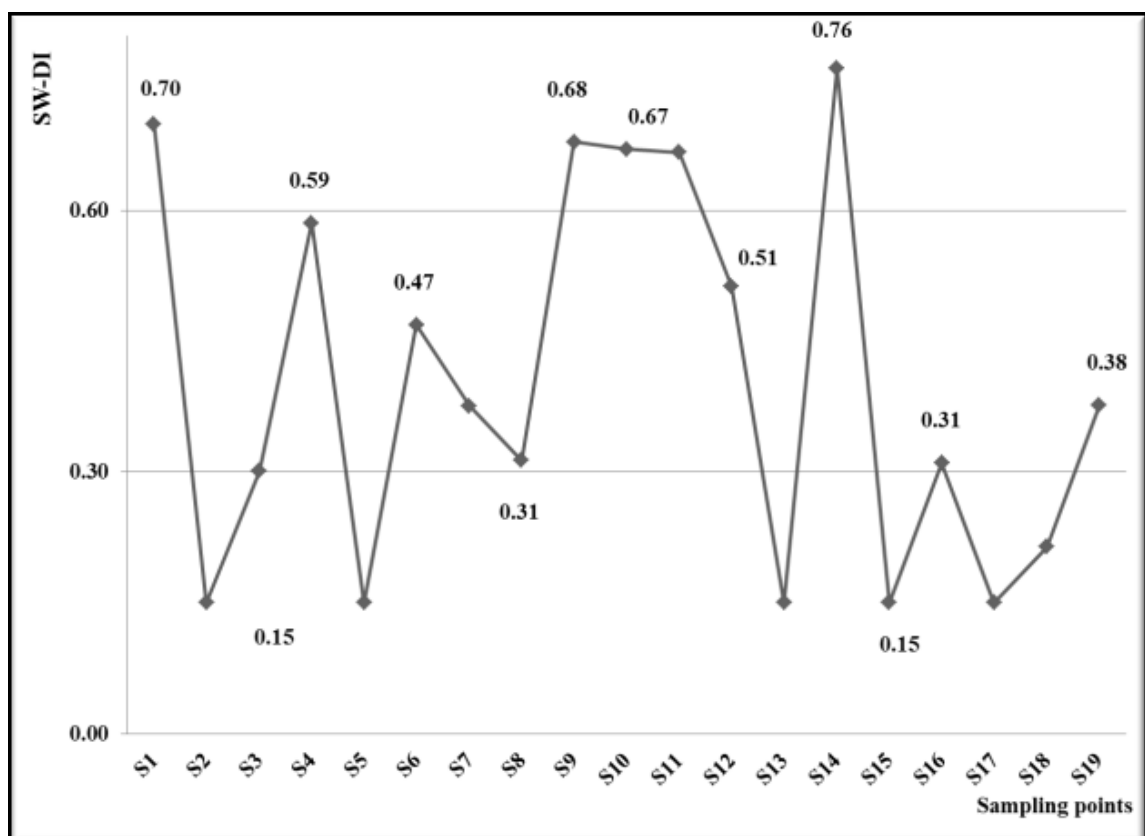

Figure 3: SW-DI values in Timiș River water catchment area, 2009.

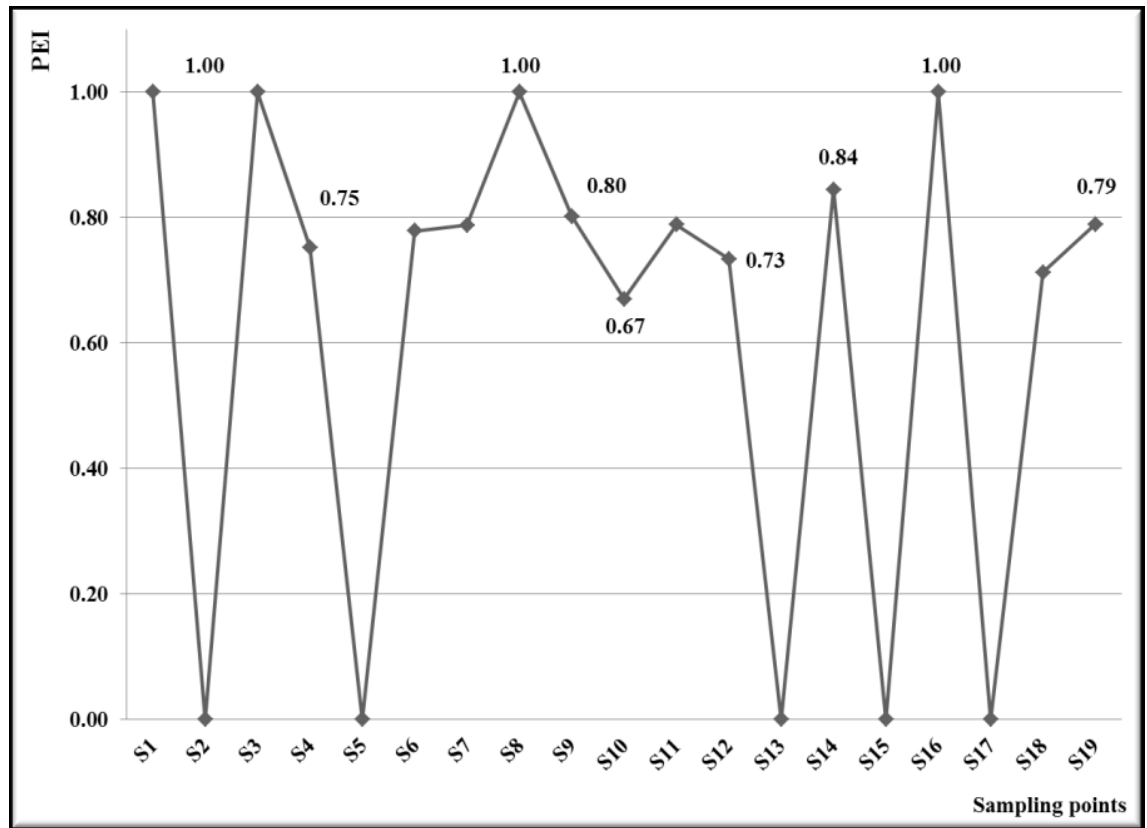

Figure 4: PEI values in Timiş River water catchment area, 2009. 
In table 2 , the water quality of the monitored stations in this study is presented based on the values of chemical parameters measured in accordance with the Ministry of Environment and Water Management (MEWA) Order 161/2006, reflecting not only the quality of the water, but also the structure of benthic fauna in the area. For table 2, the following abbreviations have been used in determining the appropriate water quality class: field marked white - class I, field marked light gray - class II, field marked dark gray - class III, field marked dark gray and bold values - class IV and field marked white and bold values - class V. $\mathrm{pH}$ values were not marked in the table, its values being in accordance with the required normal limits.

Table 2: Assigning the appropriate water quality classes for the sampling stations and the study interval in accordance with Order 161/2006.

\begin{tabular}{|c|c|c|c|c|c|c|c|c|}
\hline 梯告 & 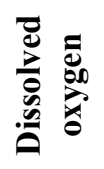 & $\tilde{U}$ & $\sum^{\infty}$ & & 莺 & 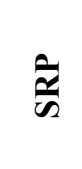 & 之彰兽 & 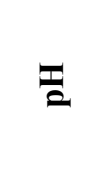 \\
\hline S1 & 8.78 & 22.50 & 9.650 & 0.30 & 0.06 & 0.07 & 0.04 & 7.08 \\
\hline S2 & 8.69 & 11.90 & 7.610 & 0.40 & 0.03 & 0.14 & 0.04 & 7.01 \\
\hline S3 & 9.00 & 11.10 & 3.740 & 0.20 & 0.001 & 0.11 & 0.08 & 7.44 \\
\hline S4 & 9.22 & 23.50 & 0.860 & 0.80 & 0.002 & 1.07 & 0.03 & 7.87 \\
\hline S5 & 9.01 & 4.42 & 16.300 & 1.10 & 0.01 & 0.78 & 0.04 & 7.74 \\
\hline S6 & 8.75 & 6.53 & 2.240 & 0.90 & 0.01 & 0.17 & 0.03 & 8.26 \\
\hline S7 & 8.73 & 9.86 & 4.870 & 0.40 & 0.01 & 0.17 & 0.04 & 7.18 \\
\hline S8 & 8.65 & 98.50 & 4.300 & 1.10 & 0.002 & 0.94 & 0.02 & 7.58 \\
\hline S9 & 8.93 & 23.10 & 2.500 & 0.70 & 0.003 & 0.07 & 0.02 & 8.02 \\
\hline S10 & 9.59 & 25.70 & 4.570 & 0.40 & 0.003 & 0.42 & 0.21 & 7.82 \\
\hline S11 & 9.03 & 12.40 & 7.300 & 0.10 & 0.01 & 0.27 & 0.07 & 7.55 \\
\hline S12 & 9.63 & 23.60 & 2.830 & 0.50 & 0.01 & 0.21 & 0.02 & 8.15 \\
\hline $\mathrm{S} 13$ & 8.16 & 18.30 & 2.000 & 0.70 & 0.01 & 0.21 & 0.02 & 6.89 \\
\hline S14 & 8.88 & 18.50 & 2.900 & 0.40 & 0.002 & 0.80 & 0.01 & 7.90 \\
\hline S15 & 8.30 & 19.90 & 1.540 & 0.40 & 0.002 & 0.61 & 0.01 & 7.52 \\
\hline S16 & 8.99 & 27.10 & 0.262 & 0.20 & 0.002 & 0.61 & 0.06 & 8.13 \\
\hline S17 & 8.20 & 23.70 & 1.680 & 0.30 & 0.003 & 0.49 & 0.03 & 7.60 \\
\hline S18 & 8.20 & 61.90 & 4.430 & 0.10 & 0.003 & 0.05 & 0.03 & 8.12 \\
\hline S19 & 9.04 & 72.40 & 26.500 & 0.20 & 0.01 & 0.30 & 0.01 & 8.22 \\
\hline
\end{tabular}


Table 3: The values of the physical-chemical parameters calculated at the 19 sites in Timiș River water catchment area, 2009.

\begin{tabular}{|c|c|c|c|c|c|c|c|c|c|c|c|}
\hline \multirow{2}{*}{ 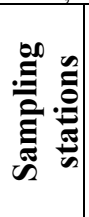 } & \multirow{2}{*}{ 离 } & \multirow[t]{2}{*}{$\frac{\pi}{2}$} & \multirow[t]{2}{*}{ 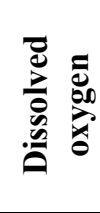 } & \multirow{2}{*}{ 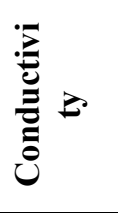 } & \multirow[t]{2}{*}{ 离 } & \multicolumn{2}{|c|}{$\begin{array}{c}\text { Dissolved } \\
\text { calcium and } \\
\text { magnesium } \\
\text { ions } \\
\end{array}$} & \multicolumn{3}{|c|}{$\begin{array}{l}\text { Dissolved inorganic } \\
\text { nitrogen forms }\end{array}$} & \multirow[t]{2}{*}{ SRP } \\
\hline & & & & & & $\mathrm{Ca}$ & $\mathrm{Mg}$ & 之莺 & 之莺 & 之 罗 & \\
\hline S1 & 15.90 & 7.08 & 8.78 & 32.20 & 3.16 & 22.50 & 9.65 & 0.30 & 0.06 & 0.04 & 0.07 \\
\hline $\mathrm{S} 2$ & 15.90 & 7.01 & 8.69 & 26.70 & 1.67 & 11.90 & 7.61 & 0.40 & 0.03 & 0.04 & 0.14 \\
\hline S3 & 19.10 & 7.44 & 9.00 & 66.00 & 1.55 & 11.10 & 3.74 & 0.20 & 0.001 & 0.08 & 0.11 \\
\hline S4 & 18.00 & 7.87 & 9.22 & 161.70 & 3.29 & 23.50 & 0.86 & 0.80 & 0.001 & 0.03 & 1.07 \\
\hline S5 & 18.70 & 7.74 & 9.01 & 141.10 & 3.76 & 4.42 & 16.30 & 1.10 & 0.01 & 0.04 & 0.78 \\
\hline S6 & 24.20 & 8.26 & 8.75 & 151.30 & 0.92 & 6.53 & 2.24 & 0.90 & 0.01 & 0.03 & 0.17 \\
\hline S7 & 19.00 & 7.18 & 8.73 & 60.40 & 1.38 & 9.86 & 4.87 & 0.40 & 0.01 & 0.04 & 0.17 \\
\hline S8 & 19.50 & 7.58 & 8.65 & 70.70 & 1.38 & 98.50 & 4.30 & 1.10 & 0.001 & 0.02 & 0.94 \\
\hline S9 & 17.30 & 8.02 & 8.93 & 131.70 & 3.24 & 23.10 & 2.50 & 0.70 & 0.002 & 0.02 & 0.07 \\
\hline $\mathrm{S} 10$ & 14.50 & 7.82 & 9.59 & 79.60 & 3.61 & 25.70 & 4.57 & 0.40 & 0.002 & 0.21 & 0.42 \\
\hline S11 & 17.00 & 7.55 & 9.03 & 55.40 & 1.73 & 12.40 & 7.30 & 0.10 & 0.01 & 0.07 & 0.27 \\
\hline $\mathrm{S} 12$ & 16.30 & 8.15 & 9.63 & 125.20 & 3.32 & 23.60 & 2.83 & 0.50 & 0.01 & 0.02 & 0.21 \\
\hline S13 & 17.00 & 6.89 & 8.16 & 141.50 & 2.57 & 18.30 & 2.00 & 0.70 & 0.01 & 0.02 & 0.21 \\
\hline S14 & 18.20 & 7.90 & 8.88 & 98.40 & 2.59 & 18.50 & 2.90 & 0.40 & 0.002 & 0.01 & 0.80 \\
\hline S15 & 19.50 & 7.52 & 8.30 & 116.60 & 2.79 & 19.90 & 1.54 & 0.40 & 0.002 & 0.01 & 0.61 \\
\hline S16 & 27.40 & 8.13 & 8.99 & 178.10 & 3.86 & 27.10 & 0.26 & 0.20 & 0.002 & 0.06 & 0.61 \\
\hline S17 & 21.10 & 7.60 & 8.20 & 136.40 & 3.33 & 23.70 & 1.68 & 0.30 & 0.001 & 0.03 & 0.49 \\
\hline S18 & 20.80 & 8.12 & 8.20 & 342.00 & 9.71 & 61.90 & 4.43 & 0.10 & 0.001 & 0.03 & 0.05 \\
\hline S19 & 15.80 & 8.22 & 9.04 & 601.00 & 16.30 & 72.40 & 26.50 & 0.20 & 0.01 & 0.01 & 0.30 \\
\hline
\end{tabular}

\section{DISCUSSIONS}

The interest in studying caddisfly larvae is sustained by their contribution to turning the allochtone material into biomass, which is then spread across upper trophic levels (Burd et al., 2008). Scientific literature sustains the role caddisflies occupy in evaluating water quality also, as well as the various degrees of tolerance to changes in qualitative parameters of water bodies (Solà and Prat, 2006; Arimoro and Ikomi, 2009; Rizo-Patrón et al., 2013).

Based on the Order 161/2006, it was established that the majority of the physicochemical parameters studied indicated a high quality of the water, belonging to class I. There were exceptions such as the concentration of the dissolved oxygen (S1, S2, S6-S9, S13-S19 class II), dissolved calcium (S8, S18, S19 - class II), dissolved magnesium (S5, S19 - class II), nitrate (S5, S8 - class II), nitrite (S1 - class III; S2 - class II) and SRP (S2, S3, S6, S7 - class II; S11-S13, S19 - class III; S5, S10, S13-S17 - class IV; S4, S8 - class V) (Tabs. 2 and 3). 
However, these exceptions have not changed the diversity of caddisflies in monitored sampling stations, SW-DI index values and those of the PEI index still being relatively high compared with other stations (Figs. 3 and 4). We believe that this is due to large numbers of individuals belonging to the tolerant species such as the representatives of the Hydropsyche, Rhyacophila and the Potamophylax genus (Tab. 1) (Graf et al., 2008).

Potamophlylax genus preference for altitudes of 150-3100 m and below $150 \mathrm{~m}$, with substrate composed of stones, gravel and boulders and also its tolerance to organic material was demonstrated in the literature (Graf et al., 2008). Lukáš and Krno (2003) for example, the species identified at the altitude of $200-450 \mathrm{~m}$ and over $450 \mathrm{~m}$. In this study, three species belonging to this genus were identified at an altitude between 240 and $490 \mathrm{~m}$ (Tab. 1). A similar pattern was set for Rhyacophila species. The literature has associated the species with $\mathrm{pH}$ values ranging from acid to alkaline and considered them tolerant (Fjellheim and Raddum, 1990; Bonada et al., 2005). High altitude dependence of these species was also demonstrated (Urbanič and Toman, 2007) signaling the presence of this species at an altitude over $500 \mathrm{~m}$. In our study, the three species were reported between 270 and $820 \mathrm{~m}$ (Tab. 1).

Also, the presence of species tolerant to changing water quality parameters as those belonging to the Hydropsyche genus may suggest that an imbalance exists, these species being generally considered to be less sensitive than other species of the order (Bonada et al., 2005; Philipson and Moorhouse, 2006). Given the presence in certain areas of some sensitive caddisfly species and that the species of the Hydropsyche genus are predatory by building a special net-spinning trap (Fuller and Mackay, 1980; Poepperl, 2000), we consider that their high number compared to the rest of the species is due to their preference for fast flowing waters such as those analyzed in the present study and by being more tolerant. Moreover, these results are suggested by low values of SW-DI and PEI diversity in 5 of the 19 stations surveyed, in all five locations only one species was identified, H. incognita (Tab. 1; Figs. 3 and B). In fact, the highest values of numerical abundance were identified for $H$. incognita with $94.74 \%$, this situation being similar for frequency in which case the maximum values were set for two species of the genus, $H$. incognita and $H$. pellucidula (Figs. 1 and 2). In general the two species replace one other in terms of altitude, but there were noted situations of coexistence (Hildrew and Edington, 1979; Miklós and Ujvárosi, 2009).

Taking into account the results of this study and those reported by the literature, we believe that the caddisfly larvae can be successfully used as biological indicators in determining the water quality. However, future detailed studies are needed.

\section{CONCLUSIONS}

Were identified 21 species included in 12 genera. The Hydropsyche genus featured the highest number of species (5), followed by the rest of the types, with three (Potamophylax sp. and Rhyacophila sp. respectively) and the rest of the species with one each. $H$. incognita and $H$. pellucidula have been identified with maximum values in terms of percentage numerical abundance and frequency.

As regarding the diversity indices SW-DI and PEI a maximum value was established for the two sampling stations (S14 - 0.76; S1 - 0.70), the lowest value of 0.15 being set for five sampling stations (S2, S5, S13, S15, S17). These low values were established by calculating the PEI index also for the same sampling stations, the maximum being identified for S8 and S16 with 1.04 and 1.03 respectively. 
The physical and chemical parameters monitored in Timiş River water catchment basin have corresponded with the limits of the MEWA Order 161/2006, which states the ecological status of surface water bodies, with a few exceptions.

\section{ACKNOWLEDGMENTS}

The main part of this study is a result of investigations in the project "The stone crayfish (Austropotamobius torrentium), distribution in Romanian habitats, ecology and genetics of populations" funded by the National Research Council (CNCS) of Romania, project code PCE-1458/2008. 


\section{REFERENCES}

1. Almeida D., Merino-Aguirre R. and Angeler D.G., 2013 - Benthic invertebrate communities in regulated Mediterranean streams and least-impacted tributaries, Limnologica, 43, 34-42.

2. Arimoro F.O. and Ikomi R.B., 2009 - Ecological integrity of upper Warri River, Niger Delta using aquatic insects as bioindicators, Ecological Indicators, 9, 3, 455-461.

3. Azrina M. Z., Yap C. K., Ismail A. R., Ismail A. and Tan S. G., 2006 - Anthropogenic impacts on the distribution and biodiversity of benthic macroinvertebrates and water quality of the Langat River Peninsular Malaysia, Ecotoxicology and Environmental Safety, 64, 337-347.

4. Böhmer J., Rawer-Jost C., Zenker A., Meier C., Feld C. K., Biss R. and Hering D., 2004 Assessing streams in Germany with benthic invertebrates: Development of a multimetric invertebrate based assessment system, Limnologica - Ecology and Management of Inland Waters, 34, 4, 416-432.

5. Bonada N., Vives S., Rieradevall M. and Prat N., 2005 - Relationship between pollution and fluctuating asymmetry in the pollution-tolerant caddisfly Hydropsyche exocellata (Trichoptera, Insecta), Archiv für Hydrobiologie, 162, 167-185.

6. Borja A., Josefson A. B., Miles A., Muxika I., Olsgard F., Phillips G., Rodríguez J. G. and Rygg B., 2007 - An approach to the intercalibration of benthic ecological status assessment in the North Atlantic ecoregion, according to the European Water Framework Directive, Marine Pollution Bulletin, 55, 1-6, 42-52.

7. Boyero L. and Barnard P. C., 2004 - A Potamophylax larva (Trichoptera: Limnephilidae) using other caddisfly cases to construct its own case, Journal of Natural History, 38, 1297-1301.

8. Burd B. J., Barnes P. A. G., Wright C. A. and Thomson R. E., 2008 - A review of subtidal benthic habitats and invertebrate biota of the Strait of Georgia, British Columbia, Marine Environmental Research, 66, 3-38.

9. Englund G., Malmqvist B. and Zhang Y., 1997 - Using predictive models to estimate effects of flow regulation on net-spinning caddis larvae in North Swedish rivers, Freshwater Biology, 37, 687-697.

10. Fernández-Aláez C., de Soto J., Fernández-Aláez M. and García-Criado F., 2002 - Spatial structure of the caddisfly (Insecta, Trichoptera) communities in a river basin in NW Spain affected by coal mining, Hydrobiologia, 487, 193-205.

11. Fuller R. L. and Mackay R.J., 1980 - Field and laboratory studies of net-spinning activity by Hydropsyche larvae (Trichoptera: Hydropsychidae), Canadian Journal of Zoology, 58, 11, 2006-2014.

12. Graf W., Murphy J., Dahl J., Zamora-Muñoz C. and López-Rodríguez M. J., 2008 Distribution and ecological preferences of European freshwater organisms, I, Pensoft Publishing House, Sofia-Moscow, 389.

13. Guilpart A., Roussel J. M., Aubin J., Caquet T., Marle M. and Le Bris H., 2012 - The use of benthic invertebrate community and water quality analyses to assess ecological consequences of fish farm effluents in rivers, Ecological Indicators, 23, 356-365.

14. Hildrew A.G. and Edington J.M., 1979 - Factors facilitating the coexistence of hydropsychid caddis larvae (Trichoptera) in the same river system, Journal of Animal Ecology, 48, 557-576.

15. Hughes S. J., 2006 - Temporal and spatial distribution patterns of larval trichoptera in Madeiran streams, Hydrobiologia, 553, 27-41.

16. Ilie A. C., 2007 - Complexul spaţial al bazinelor râurilor, Edit. Fundaţiei România de Mâine, București, 212. (in Romanian)

17. Kail J., Arle J. and Jähnig S.C., 2012 - Limiting factors and thresholds for macroinvertebrate assemblages in European rivers: Empirical evidence from three datasets on water quality, catchment urbanization, and river restoration, Ecological Indicators, 18, 63-72.

18. Li L., Zheng B. and Liu L., 2010 - Biomonitoring and Bioindicators Used for River Ecosystems: Definitions, Approaches and Trends, Procedia Environmental Sciences, 2, 1510 1524. 
19. Lukáš J. and Krno J., 2003 - Caddisflies (Trichoptera) of the Gidra River basin, Acta Zoologica Universitatis, 45, 69-75.

20. Miklós B. and Ujvárosi L., 2009 - Distribution patterns of Hydropsyche incognita (Pitsch, 1993 ) and H. pellucidula (Curtis, 1834) in Transylvania (Romania), with special reference to their ecological requirements (Trichoptera: Hydropsychidae), Bulletin De La Société Des Naturalistes Luxembourgeois, 110, 167-172.

21. Order 161/16.02.2006 approving the (Norms concerning the classification of surface water quality in order to determine the ecological status of water bodies), 122. (in Romanian)

22. Ouyang Y., 2005 - Evaluation of river water quality monitoring stations by principal component analysis, Water Research, 39, 12, 2621-2635.

23. Philipson G. N. and Moorhouse B. H. S., 2006 - Observations on ventilatory and net-spinning activities of larvae of the genus Hydropsyche Pictet (Trichoptera, Hydropsychidae) under experimental conditions, Freshwater Biology, 4, 525-533.

24. Poepperl R., 2000 - The Filter Feeders Hydropsyche angustipennis and H. pellucidula (Trichoptera: Hydropsychidae) in a Northern German Lowland Stream: Microdistribution, Larval Development, Emergence Pattern, and Secondary Production, Limnologica, 30, 65-72.

25. Rizo-Patrón F. V., Kumar A., McCoy Colton M. B., Springer M., Florencia A. and Trama F. A., 2013 - Macroinvertebrate communities as bioindicators of water quality in conventional and organic irrigated rice fields in Guanacaste, Costa Rica, Ecological Indicators, 29, 68-78.

26. Roy A. H., Rosemond A. D., Paul M. J., Leigh D. S. and Wallace J. B., 2003 - Stream macroinvertebrate response to catchment urbanisation (Georgia, U.S.A.), Freshwater Biology, 48, 329-346.

27. Sîrbu I. and Benedek A. M., 2004 - Ecologie practică, Edit. „Lucian Blaga” University of Sibiu, 254. (in Romanian)

28. Solà C. and Prat N., 2006 - Monitoring metal and metalloid bioaccumulation in Hydropsyche (Trichoptera, Hydropsychidae) to evaluate metal pollution in a mining river. Whole body versus tissue content, Science of The Total Environment, 359, 1-3, 221-231.

29. Stan G., 1995 - Metode statistice cu aplicații în entomologie, Buletinul informativ al Societăţii Lepideptorologice Române, 6, 67-96. (in Romanian)

30. Urbanič G. and Toman M. J., 2007 - Environmental Variables on Stream Caddis Larvae in Three Slovenian Ecoregions: Alps, Dinaric Western Balkans and Pannonian Lowland, International Review of Hydrobiology, 92, 582-602.

31. Van Hoey G., Borja A., Birchenough S., Buhl-Mortensen L., Degraer S., Fleischer D., Kerckhof F., Magni P., Muxika I., Reiss H., Schröder A. and Zettler M. L., 2010 - The use of benthic indicators in Europe: From the Water Framework Directive to the Marine Strategy Framework Directive, Marine Pollution Bulletin, 60, 12, 2187-2196.

32. Wallace I. D., Wallace B. and Philipson G. N., 2003 - Case-bearing caddis larvae of Britain and Ireland, Edit. Freshwater Biological Association, UK, 1-156.

33. Waringer J. and Graf W., 1997 - Atlas der Österreichischen Köcherfliegenlarven, Edit. Facultas Universitätsverlag, Wien, 19-219. (in German).

34. Wesolek B. E., Genrich E. K., Gunn J. M. and Somers K. M., 2010 - Use of littoral benthic invertebrates to assess factors affecting biological recovery of acid- and metal-damaged lakes, Journal of the North American Benthological Society, 29, 2, 572-585. 